\title{
SEEMINGLY INCONSISTENT: \\ "GROWING SOUTHERN PLANTS THE MICHURIN METHOD" BY WERONIKA MUREK \\ AND FIVE SPICE STREET BY CAN XUE
}

\begin{abstract}
A bstract. The comparison of the works of the Chinese writer Can Xue and the Polish writer Weronika Murek allows us to notice the existing thematic and formal similarities between them. Despite the visible differences, the writers have many points in common - in their works both have given up the action line, unity of action and place, both reach for surrealism, absurdity, grotesque and paradox. The works of Can Xue and Murek prove the validity of the term world literature, which is sublimation of human spirit and in its deepest layer is common to all people, regardless of their origin, culture and language.
\end{abstract}

Key words: Can Xue; Weronika Murek; Chinese literature; Polish literature; world literature.

The very title of this article seems to do good on the promise of incompatibility and inconsistency: putting the names of these two authors next to each other may come as a surprise. Weronika Murek, born in 1989, is mainly known for her literary debut: a collection of short stories entitled Uprawa roślin potudniowych metoda Miczurina ("Growing Southern Plants the Michurin Method") published in 2015. Can Xue on the other hand, born in 1953, is a well-renowned author who has been actively publishing since 1987. She is credited with a long list of accomplishments in both literature and literary critique. It may seem hazardous to embark on a quest of comparing the texts by the authors who differ so wildly as per their age, nationality, cultural background and life experiences. It may seem far-fetched to seek out if not the kinship of souls, then maybe at least similarities in the

Katarzyna Sarek, PhD - Jagiellonian University in Krakow, Faculty of Philology, Institute of Oriental Studies, Department of Japanese Studies and Sinology; e-mail: katarzyna.sarek@uj. edu.pl. ORCID: https://orcid.org/0000-0002-4298-6301. 
ways they think and see the world, as reflected in their work. However, it should be considered that as David Darmosh puts it, world literature cannot be divided into separate, sometimes contradictory literary tradition. Nor should it be considered one global voice overarching all cultures. It should rather be regarded as a continuum of interconnected works and their interpretations (Damrosch 5). Moreover, the moment a literary work goes beyond the restraints of its own language and culture, it quite obviously loses what is impossible to convey in translation. At the same time, however, it becomes enriched with new interpretations. For this very reason, comparing works seemingly distant as per subject and form can lead to interesting conclusions and identification of universal tropes and meanings. Haun Saussy claims every comparative project is, to a degree, an experiment (Saussy 595), since the analysts come from various cultural backgrounds, have various degrees of knowledge and life experiences and so their attention will naturally be attracted to different phenomena and tropes, which may result in drawing even contradictory conclusions.

Differences in works by these two authors are easily identified. However, similarities and shared visions providing for similar resonance can also be easily spotted. Neither Murek nor Can Xue feel the need to fit into existing mold. They scoff at the linear narratives, hold no regrets when dropping the action line, unity of time and space, and even common sense or logics that normally require the characters to be of certain age, have a specific appearance, or, at least, be alive (character in one of the Murek's stories is dead). Absurdity, surrealism, settings full of paradoxes, where nothing is certain and obvious, where there is nothing to hold on to and breathe a sigh of relief that at least something here makes sense - they all, like transparent and extremely robust fishing lines, tie "Growing Southern Plants the Michurin Method" by Murek to Five Spice Street by Can Xue.

In order to understand how exceptional Can Xue's position on the Chinese literary scene is, as well as to understand her courage in crossing all boundaries, it is necessary to explore her works and examine her characters against the backdrop of traditional female roles in the Chinese culture. Patricia Ebrey in her book Women and the Family in Chinese History claims that Confucianism sanctions the patriarchy as a social model based on eternal dominance of elders and male members of the society over the younger generations and women (Ebrey 11-12).

Cultural and social changes that took place in China after the fall of the Qing empire in 1911 and as a result of May $4^{\text {th }}$ Movement have led to the 
emergence of female authors on the Chinese literary scene and to introduction of a new, feminine style, language and topics. The breakthrough came with the short story by Ding Ling Miss Sophie's Diary, where the main character-pampered, manipulative hypochondriac - openly expresses her desires and emotions, some of which are truly unbecoming of a young lady. Ding Ling has laid bare the dilemmas that Chinese women searching for their identity and struggling to break free from ancient norms and restrictions faced at the time. Their attempts at emancipation were not met with understanding by the society and their families. Women who made an effort to live "a modern life" bumped against a wall of disapproval and had very little support (Hershatter passim). It quickly became evident that the new ideology - communism - despite being vocal about equal rights between the sexes, brought no real changes in the mentality and social behavior in this regard. Men and men-centered topics dominated the Chinese literature for long decades under the Communist rule. Alongside the realism and the so-called new socialist literature, they were at the forefront of the Chinese literary scene until the end of the Cultural Revolution in 1978. It was only in the 1980's that a wave of economic and cultural opening and reforms swept through the country initiating changes reflected in art and culture. During 1980 's quite a few new authors who adopted a different style and created works regarding topics and using language unlike anything written in the previous eras entered the Chinese literary scene.

Can Xue was one of the most outstanding and interesting new writers of that decade. Her unusual style and uniqueness of the topics she explored quickly drew the attention of the literary critique both in China and abroad. The translator of one of her works wrote in the foreword: "Can Xue is an anomaly of the Chinese literature" (Innes ix) and as weird as this compliment is, there is no doubt it expresses the translator's deep admiration for Can Xue's originality. Can Xue (残雪), whose real name is Deng Xiaohua (邓 小华), is often referred to as Bruno Schulz of modern China (Who's who in Contemporary Women's Writing 53). She is one of the most intriguing persona of the Chinese literary world and a highly distinctive voice in the modern Chinese literature (Duke xi). Her artistic pseudonym stands for "dirty, springtime snow that refuses to melt." It is both a reflection of how she sees herself and how she wants to be seen by readers and critics - as a person who stands stubbornly on the side, refusing to adapt to external conditions regardless of circumstances. This image has been extremely effectively imposed on her audience. Due to Cultural Revolution, Can Xue never managed to get full secondary education. As a teenager she performed manual labor in 
a factory and when in the 1980s private economic activity was finally allowed, she and her husband opened a tailor shop. She embarked on her literary career at the beginning of $1980 \mathrm{~s}$ and by the time the decade drew to a close, she grew to be considered representative of a budding, literary avant-garde movement that counted among its members some of the most prominent names of modern Chinese literature: Mo Yan, Yu Hua, Ge Fei. Until today, Can Xue has published six novels, over 50 novellas, ab. 150 short stories and six collections of literary critique essays (Porochista).

Can Xue's writing is a marriage of the grotesque with the absurd. Sometimes called "daughter of Kafka and Borges," the authoress admits that works by these two writers inspired her and exerted so strong an impact that she became a "foreign plant growing in the five thousand-years old Chinese soil" (Suher and Hua). The specific manner in which she constructs her narratives, surprising way in which she uses the language and unusual characters make her writings stand out so much among all Chinese and foreign writers that just a few lines suffice to identify her as their author. Chinese literary critique doesn't dissimulate their reluctance towards Can Xue and describes her work as crazy, emotional, impossible to read or understand, and filled with nightmarish visions. Undissimulated misogyny has them label Can Xue as "a paranoid woman afraid of being hurt by the world." Their objections focus on two things: (a) surreal descriptions of a world deprived of logics, unconventional narration that lacks chronology or spatial reference points, (b) absence of a well-defined thread that would lead the plot towards any kind of finale or resolution (Rong Cai 96). According to Can Xue, pure literature, a term she uses to describe her writing, should be judged on the basis of the spiritual depth of the exploration of the human soul. The writer interprets purity as a depth that entails darkness and means width and freedom. Writers of pure literature are engaged in transgressing the world of experience to discover the infinite kingdom of the soul. For Can Xue, pure literature is a spatialized connection between the spiritual world and the corporeal reality (Can Xue, Dance of the Dark Soul).

It is interesting to note that Polish critique - though much less hostile because of their acquaintance with postmodernism and its experiments voiced similar objections towards Weronika Murek after her literary debut in 2015. Collection of her short stories under an unusual title (why Michurin? Why growing plants? Why southern plants?), however modest in volume, has been both nominated for various awards and awarded a number of prizes.

\footnotetext{
${ }^{1}$ Summary of opinions of Chinese critics in Lu Tonglin 175-179.
} 
It has also provoked a widespread reaction, having been reviewed and analyzed by a number of publicists and critics. The narrative constructed around paradoxes, surprising and refreshing use of language, absurdities shining through the thin layer of everyday triviality have been widely appreciated and Weronika Murek was recognized a new, fresh voice on the Polish literary scene. ${ }^{2}$ Her unusal writing is a unique phenomenon, she mixes supernatural themes, as well as religious ones, and with elements of folklore and reportage she creates a strange universe full of surreal imagery. Inside of the dreamlike and cinematic atmosphere of her stories she sneaks extraordinary permeating the real and mundane world. She shift suddenly perspectives but the narrative remain embedded in reality creating a mismatch between the reader's expectations and the text being read.

Weronika Murek, graduate of law that, as she puts it, made her suspicious about the language admits in the interviews: "I get bored by sheer copying of reality, by this scrupulous, painstaking retracing of its contours. Every single time I feel terribly tempted to add some opening here and there, insert an inset" (Sowińska, "Lubię, jak się nie zgadza"). In her stories, these safety exits sometimes grow to become real gateways to different dimensions. In a story "Back, down, left," the very first sentence: "She was the last one to know she is dead" (Murek, Uprawa) makes the reader feel a huge draft sweep away all logics. The reader is left standing next to dead Maria, watching with no emotion how the world reacts to her death, removes traces of her worldly existence from her apartment and office, readies her corpse for the burial. Characters in Murek stories function in a space separated from reality and, what's more, they take it for granted - no one seems surprised at the dead Maria walking the streets, hot water getting burned, lunatics teaching the cock how to hate and a cosmonaut flying to the Moon to talk to the ghosts. "It happens"-Murek magnanimously suggests that a shrug is the sole adequate reaction to an absurdity, then another.

Also the inhabitants of Five Spice Street seem immune to deviations from reality. Within the enclosed space, isolated from the outside world, that they inhabit, strange and unusual things happen. Sheer presence and impossibility to establish basic facts about Madam X, who appears suddenly and out of nowhere amidst a closely tied community, shakes the order of things: "Madam X's age became a major issue on our street. When anyone left

${ }^{2}$ E.g. justification for the nomination for Polityka 2015 Passports and the opinions of several jury members cited therein. "Za co nominowaliśmy Weronikę Murek"; Nawrot, Weronika Murek: W rzeczywistości inaczej. 
a group, he stood his own ground, and so at least twenty eight different views flourished. No one wanted to argue continuously anymore" (Can Xue, Five Spice Street 5). ${ }^{3}$ Also Madam X's looks stir controversies. Inhabitants of Five Spice Street argue about her being pretty and ugly, and the novel contains plenty of contradictory descriptions:

The controversy about her age was part of a generally vague and contradictory image of Madam X. She is a middle-aged woman, very thin, with white teeth, a neck that's either slender or flabby, skin that's either smooth or rough, a voice that's either melodious or wild, and a body that's either sexy or devoid of sex. When this obscure image takes us by surprise and 'discloses its true face,' everything unfathomable becomes clear, but only for an instant. Let's put it aside for now. (Can Xue, Five Spice Street 6) ${ }^{4}$

It's not enough that it's impossible to tell her age and describe her appearance. Madam X gets on her neighbors' nerves by dazzling everyone with her sexiness, shamelessness (she swims naked in the river and then sunbathes at the riverside) and frivolous approach towards carnal men-towomen relations. She talks about sex and her sexual life openly, doesn't care for being accused of immorality and bad conduct. Madam X is a challenge to patriarchy, slap in the face of a prudish and deeply conservative society that seeks to impose a single behavioral and moral norm on all its members like in communist China that claimed the right to control and oversee sexual life of its citizens, women in particular.

Non-conformant behavior, flippancy, courage to talk about topics considered taboo turn Madam X into the most important, local celebrity that becomes subject of most conversations and musings by inhabitants of Five Spice Street. Can Madam X perform magic? What are those "diversions to dispel boredom" and "mischief makings" that take place all night long in her bedroom? How old is she, in the end? What, the hell, does she look like? Who is her lover? Neighbors are haunted by a million of unanswered questions. Not even the narrator can help them solve the mystery surrounding Madam X. At first, narrator makes an effort to collect confessions, put the stories into some kind of order, get to the bottom of things as recounted in

3 “久而久之, X女士的年龄便成了我们这条街上一个最大的疑案。而一离开体意识，大家 又各执已见，将见解分裂为 28 种以上，并谁也懒得追究谁了”(3).

4 “通过对于年龄的种种议论, 我们现在得出了这么一个不协调的模糊印象：X女士是一 个中年妇女, 牙齿白, 身体瘦, 脖子细长或粗短, 皮肤光滑或粗糙, 声音清脆或放浪, 外表 性感或毫无半点性感。这个模糊的印象有时会出其不意地在刹那间 “ 露出庐山真面目”, 继而又一切如旧, 还原为高深莫测, 模糊斑驳的一团, 者些都是后话。” (4) 
a number of sometimes contradictory tell-tales but eventually gives up with no more than a helpless shrug. The truth cannot be established. The reader cannot rely on the narrator's omniscience, cannot count on the narrator to quietly feed them missing information and give a clue on how to interpret this or that (assuming the traditional interpretation method, i.e. "what is it that the author is trying to say?" is adopted). Facts do not exist on Five Spice Street. What does exist are the contradictory opinions and mutually exclusive interpretations.

Realism and facts are not to be found in Murek's work either. Even after the reader accepts the absurdity of the situation and obvious tears in the fabric of reality - the dead Maria takes us on a tour of the remains of her worldly existence and tea party for the dead starts to sound like fun - there comes a strong pull removing from under our feet the distorted and flimsy footholds that with all seriousness had been offered to the reader at the beginning of the story. Maria peeks into the coffin and freezes: "It wasn't her. It was not her body" (Murek, Uprawa 50). Whose was it then? How can it be anyone else's if previous inspections by family and Maria herself confirmed its identity? Other stories by Murek rely on the same pattern: we can never be certain that presented facts are fixed once and for good, the reality is fluid and what is more, everything can change depending on the point of view. In the story entitled "Third burial of general Sikorski, including the blanket," the narrator presents us with two different perspectives the bird's eye view and frog's eye view - that draw our attention to different characters and details. With the bird's eye we can see "a group of blind men forming three quarters of the march," with the frog's — "only a mime dressed up as a tiny baroque nobleman" (Murek, Uprawa roślin poludniowych 124). Moreover, characters of Murek's stories are located "nowhere": depictions of surroundings provide no clues on the geographic location of the events, even if the selection of dishes and appetizers (headcheese, pearmains, onion cakes, challah bread ...) do suggest it might be a certain country known to the authoress and not that far away. Objects appear only when the characters need them. Given that Murek is consistent in her doling out the information to the readers, avoiding all unnecessary adjectives, descriptions and ornaments, it is not surprising that the moment in time and timing in general remain unknown as well. Sometimes it's dusk, sometimes the fall arrives - in Murek's world where calendars are not needed, only the rhythms of nature reflect the category of time. 
Can Xue's characters are "enclosed" within family or social relations. It is striking to see that Madam X is presented in opposition to other people The Others. These two opposing sides have little warm feelings for each other and are mutually suspicious. They are, however, conjoined by symbiotic ties that it's impossible to sever. Can Xue lays bare the dark sides of human psyche and existence. Her works are full of crippled, degenerated human relationships that, as Western literary critics claim, reflect the inhuman reality of life in communist China (Wu Liang 129-130). Nonetheless, the writer has spent years refusing to accept that her works might be interpreted from the perspective of politics and historical events like the Cultural Revolution or Anti-Rightist Campaign. ${ }^{5}$ No visible cordiality or tenderness can be found among family members in Murek's stories either. Mother of the dead Maria isn't exactly bereaved. She dresses her daughter' corpse in an old sweater and when the dead voices her protest, the mother replies straightforwardly: "Cause we thought it too stylish. Pity to give it away. The earth won't appreciate, will it?" (Murek, Uprawa 17). In Murek's prose, neither the human mother nor the Holy Mother show mercy or sympathy. When Maria eventually leaves the world of the living and goes to paradise, it turns out that the eternity stretching before her looks more like mental torture than anything else - she is supposed to spend it holding a ball of yarn for Virgin Mary who's knitting socks for Jesus.

In most of her works, Can Xue's narrative is recounted in the first person, by an omniscient narrator - the reader is never confronted with any other perspective, sees the world through the narrator's lens and gets trapped in their visions and madness (Wedell-Wedellsborg 9-10). The writer often refuses to name her characters. She uses Latin alphabet letters accompanied by an honorary title instead (Mr, Ms, Madam, doctor) or simply provides the name of a profession, social function or marital status p.ex. doctor, neighbor, widow. Thus, her characters never become full, specific individuals but embody personality types or clusters of certain character traits.

Murek plays similar tricks on the readers in her stories. Most of her characters are either "woman," "man" or are defined by their profession, social function or a distinctive detail (hearse driver, Walker, inspector, the woman with a glove). During an interview, when asked why she never uses surnames or names, Murek refuses to acknowledge she consciously resorts to this simple, narrative trick of creating the "everyman" figure. She insists on the aesthetic argument instead: "As for the names ... I am simply put off

\footnotetext{
${ }^{5}$ For example, in an interview in 2001, "Stubbornly Illuminating."
} 
by the Polish names and surnames. They spoil the melody of the sentence, all these Kowalskys and Mureks. All the more I wouldn't be able to use foreign names, that would be pretentious" (Sowińska, "Lubię, jak się nie zgadza").

Other works by Can Xue feature types of characters that are absent or at least very rare in Chinese literature. It's best exemplified by the mother figure which - in Can Xue's writing - has nothing to do with the traditional mother image and its depictions by other Chinese authors. With one sharp move Can Xue deprives mothers of their aura of sanctity and shows the world their dark side, the face distorted by anger and hatred. In Five Spice Street, Madam X is not so much a cruel as an indifferent and distant mother but in other works mothers are neither good, gentle nor full of sacrificethey are self-centered, repulsive and spiteful. In a story entitled "Hut on a mountain" that was published in 1985 and is considered representative of all Can Xue's writing, the main character is a little girl, alienated and lonely among family members who don't pay any attention to her. The story is written in a nightmarish style and filled with outlandish events. We watch this distorted world through the eyes of the little girl who narrates the story. Despite shocking and truly horrific situations that she finds herself in every step she takes, it is her mother that only truly fills her with dread: “[...] Keeping her eyes on the floor, Mother pretended she knew nothing about it. But I had a feeling she was glaring ferociously at the back of my head since the spot would become numb and swollen whenever she did that" (Can Xue, Hut on the Mountain 212). ${ }^{6}$ Even innocent behavior by the child triggers her mother's aggression, which - repressed - results in self-harm: "Little Sister sneaked in and told me that Mother had been thinking of breaking my arms because I was driving her crazy by opening and shutting the drawers. her crazy. She was so tortured by the sound that every time she heard it, she'd soak her head in cold water until she catches a bad cold" $(215) .^{7}$ Mother directs threats at her daughter in every conversation, accuses her of viciousness and wants to make her feel guilty by claiming she was the reason why her father attempted to commit a suicide. Mother in Can Xue's story becomes the main enemy of her children and seems to draw pleasure and sense

\footnotetext{
${ }^{6}$ Can Xue, Shan shang de xiao wu 68: “[...] 妈妈假装什么也不知道，垂着眼。但是她正恶狠 狠地盯着我的脑后勺, 我感觉得出来。每次她盯着我的脑后勺, 我头皮上她盯的那块地方就 发麻, 而且肿起来.”

${ }^{7}$ Can Xue, Shan shang de xiao wu 68: “小妹偷偷跑来告诉我, 母亲一直在打主意要弄断我 的胳膊, 因为我开关抽屉的声音使她发狂, 她一听到那声音就痛苦得将脑袋浸在冷水里, 直 泡得患上重伤风.”
} 
of satisfaction from her status as such. She opposes her children's attempts at independence and efforts to leave the family home, she never allows her children to develop a separate identity, personality and mature into adults.

Madam X as a character created by Can Xue is an open challenge to the petrified image of women in Chinese literature. In contrast with the Chinese literary tradition, Can Xue's Madam X feels free from the burden of obligations towards family or society in general. She acts on her whims and according to her own wishes. She is at best indifferent towards her child, husband and lovers; cruel and ruthless at worst. Madam X, just like other female characters in Can Xue's writings, destroys the image of women created by men as sublimation of their inner needs and desires (Xie Nandou 2731, passim).

Can Xue's works seem to be her answer, even if only a subconscious one, to disasters, fears and calamities brought upon the Chinese society as a result of decades of political and social upheaval, and which might have traumatized her as a little child (her parents were sent to labor camps, she was deprived of medical care, almost died of starvation and performed hard physical labor since a very tender age). In her narratives, Can Xue avoids any kind of references to real political events and prefers to focus on relationships among people joined by close, interpersonal ties - nuclear family members, extended family members, lovers. However, the deformed and distant reflection of the realities and general ambiance of the times of her youth and early adulthood shines through her seemingly apolitical works. Mistrust, suspicion, hostility - attitudes that allowed people to survive the dog-eat-dog eras - are seen to have permeated even the most intimate human relationships. In the official propaganda in Mandarin Chinese, the word "mother" stood for the Communist Party of China, while the Chinese people were her "children." Can Xue's mother indeed is like the Party - she is the central character, the key character around whom life of the whole family revolves. Life of other family members hangs on her whims and wishes, she is cruel, ruthless and domineering. Children - the citizenshave no choice but to obey and do her bidding but they dream of escape. When the chance to escape comes their way and they get to taste the freedom, they find themselves unable to function on their own: their mother provided them with no positive role-models, feeding them the degenerated image of human-to-human relations and watching them develop personalities of obedient slaves (Rong Cai 124-126). 
Both writers, Can Xue and Murek, are amazed with the reality. They tear its fabric open so that it lays there bare, deprived of protection that our senses and logics normally provide reality with. The world created by Murek is not really for those made of flesh: the missing boundary between dream and reality cancels out all realism and likelihoods. The authoress forces us to leave our habits behind, encouraging readers to look at the world again, either with a child's eyes or with the eyes of a scientists who refuses to accept that "it simply can't be." Murek offers us a clue hidden in the seemingly incoherent title of the collection of her short stories: let us all learn from Michurin - Russian researcher who worked to create new types of crop plants, crossing the confines of the science of his time to expand our understanding. The world created by Can Xue is just as "outworldly": Can Xue depicts the world of the spiritual, analyzing emotions and thoughts. Material reality is in her eyes only one piece of the whole puzzle or, maybe even nothing more than just a necessary wrapping for her character's souls.

It is, of course, possible though highly unlikely that Can Xue has ever heard of Weronika Murek or that Weronika Murek was inspired by Can Xue's work - so far, it has not been even translated into Polish, her native tongue. But it is beyond doubt that these two authors share a certain kind of sensibility and worldview, as reflected in their writing. This goes to prove that the words by David Darmosh quoted at the beginning of this paper ring true: no matter the apparent inconsistencies and incompatibilities, literature remains to be the sublimation of human spirit, its sensibility and sensitivity, and despite all cultural and language barriers, these are not as far from each other as some of us might want to think.

\section{BIBLIOGRAPHY}

Can Xue. Dance of the Dark Soul (Heian linghui de wudao 黑暗灵魂的舞蹈). Wenhui chubanshe 文汇出版社, 2009.

Can Xue 残雪 Shan shang de xiao $w u$ 山上的小屋. Renmin Wenxue 人民文学, 1985, No. 5, pp. 67-69. English edition: Hut on the Mountain. Translated by Ronald Janssen and Jing Zhang. China's Avant-Garde Fiction: An Anthology, edited by Jing Wang, Duke University Press Books, 1998, pp. 212-216.

Can Xue. Chatka na górze. Translated by Zofia Jakubów. Kamień w lustrze. Antologia literatury chińskiej XX i XXI wieku, edited by Lidia Kasarełło, Państwowy Instytut Wydawniczy, 2019, pp. 465-470.

Can Xue 残雪 Wu xiang jie 五香街. Fuzhou, 2002. English edition: Five Spice Street. Translated by Karen Gernant and Chen Zeping, Yale University Press, 2009. 
Damrosch, David. What is World Literature? Princeton University Press, 2003.

Ding, Ling. Pamiętnik panny Sophie. Translated by Irena Kałużyńska. Współczesne opowiadania chińskie, t. 1: Lata 1918-1944, Wydawnictwo Uniwersytetu Warszawskiego, 1995, pp. 87-117.

Duke, Michael S. Modern Chinese Women Writers: Critical Appraisals. Routledge, 1989.

Ebrey, Patricia B. Women and the Family in Chinese History. Taylor \& Francis, 2003.

Guisso, Richard W. "Thunder Over the Lake: The Five Classics and the Perception of Woman in Early China." Historical Reflections/Réflexions Historiques, vol. 8, no.3. WOMEN IN CHINA: Current Directions in Historical Scholarship, 1981, pp. 47-61.

Hershatter, Gail. Women in China's Long Twentieth Century. University of California Press, 2007.

Innes, Charlotte. "Foreword." Old Floating Cloud by Can Xue, translated by Ronald R. Janssen and Jian Zhang, Northwestern University Press, 1991.

Lu, Tonglin. "Can Xue: What Is So Paranoid in Her Writings?" Gender and Sexuality in TwentiethCentury Chinese Literature and Society, edited by Lu Tonglin, State University of New York Press, 1993, pp. 175-204.

Murek, Weronika. Uprawa roślin potudniowych metoda Miczurina. Wydawnictwo Czarne, 2015.

Nawrot, Jolanta. "Weronika Murek: W rzeczywistości inaczej.” Zamek czyta, www.zamek czyta.pl/ weronika-murek-rzeczywistosci-inaczej/. Accessed 22.12.2019.

Porochista, Khakpour. "The Performance of Fiction: An Interview with Can Xue." Words without Borders, www.wordswithoutborders.org/dispatches/article/the-performance-of-fiction-an-interviewwith-can-xue-porochista-khakpour. Accessed 20.12.2019.

Rong, Cai. The Subject in Crisis in Contemporary Chinese Literature. University of Hawai'i Press, 2004.

Rosenlee, Li-Hsiang Lisa. Confucianism and Women: A Philosophical Interpretation. SUNY Press, 2006.

Saussy, Haun. “'Wyborny trup' pozszywany ze świeżych koszmarów. O memach, pszczelich rojach i samolubnych genach.” Niewspólmierność. Perspektywy nowoczesnej komparatystyki. Antologia, edited by Tomasz Bilczewski. Wydawnictwo Uniwersytetu Jagiellońskiego, 2010.

Sowińska, Agnieszka. "Lubię, jak się nie zgadza. Rozmowa z Weroniką Murek." Dwutygodnik, 02/2015.152, www.dwutygodnik.com/artykul/5727-lubie-jak-sie-nie-zgadza.html. Accessed 20. 12.2019.

"Stubbornly Illuminating 'the Dirty Snow that Refuses to Melt': A Conversation with Can Xue." Interviewed by Laura McCandlish. MCLC Resource Center, 8 Nov. 2014, u.osu.edu/mclc/ online-series/mccandlish/. Accessed 19.12.2019.

Suher, Dylan, and Joan Hua. "An interview with Can Xue." Asymptote Journal, www.asymptote journal.com/interview/an-interview-with-can-xue/. Accessed 19.12.2019.

Wedell-Wedellsborg, Anne. "Ambiguous Subjectivity: Reading Can Xue." Modern Chinese Literature, vol. 8, no.1/2, 1994, pp. 7-20.

Who's who in Contemporary Women's Writing, edited by Jane Eldridge Miller, Psychology Press, 2001.

Wu, Liang. "Re-membering the Cultural Revolution. Chinese Avant-Garde Literature of the 1980s." Chinese Literature in the Second Half of a Modern Century: A Critical Survey, edited by PangYuan Chi and David Der-wei Wang, Indiana University Press, 2000, pp. 124-136. 
Xie Nandou 谢南斗. “Can Xue yu nuxing wenxue 残雪与女性文学." Zhongguo wenxue yanjiu 中 国文学研究, no. 2, 2002, pp. 27-31.

"Za co nominowaliśmy Weronikę Murek." Polityka, 2016.01.09, www.polityka.pl/tygodnik polityka/kultura/paszporty/1646674,1,za-co-nominowalismy-weronike-murek.read. Accessed 25.12.2019.

\section{Z POZORU NIESPÓJNE: \\ HODOWLA ROŚLIN POEUDNIOWYCH METODA MICZURINA \\ WERONIKI MUREK I FIVE SPICE STREET CAN XUE}

\section{Streszczenie}

Porównanie dzieł chińskiej pisarki Can Xue i polskiej pisarki Weroniki Murek pozwala dostrzec istniejące $\mathrm{w}$ nich podobieństwa tematyczne i formalne. Pomimo widocznych różnic, pisarki mają wiele wspólnych punktów - w swoich pracach obie zrezygnowały z linii akcji, jedności akcji i miejsca, obie sięgają po surrealizm, absurd, groteskę i paradoks. Prace Can Xue i Weroniki Murek potwierdzają słuszność terminu „literatura światowa”, który jest sublimacją ludzkiego ducha, a jego najgłębsza warstwa jest wspólna dla wszystkich ludzi, niezależnie od ich pochodzenia, kultury i języka.

Słowa kluczowe: Can Xue; Weronika Murek; literatura chińska; literatura polska; literatura światowa. 